\title{
Research on the Strategy of Widening the Offshore Service Outsourcing --Based on Anhui Province. China
}

\author{
Zehu $\mathrm{Jin}^{1, \mathrm{a}}$, Yumei $\mathrm{He}^{1, \mathrm{~b}}$ \\ ${ }^{1}$ School of economics, Anhui university, China \\ ${ }^{2}$ School of economics, Anhui university, China \\ a12015@ahu.edu.cn, b971590195@qq.com
}

Keywords: OBOR;Offshore Service Outsourcing; GEM Model;Factor Analysis

\begin{abstract}
Combined with the development characteristics of China's international service outsourcing industry, study the current situation, competitiveness, problems, opportunities and countermeasures of the service outsourcing industry of Anhui province based on eight cities (Hefei,Chongqing,Wuhan,Chengdu,Nanchang,Changsha,Zhengzhou,Xian)using the GEM modified model and factor analysis in order to plan the developing strategy of service outsourcing industry in Anhui Province and broaden the development route of service outsourcing.
\end{abstract}

\section{Introduction}

In recent years Anhui province has increased investment in the tertiary industry, encourage the development of this industry, rapid development of service outsourcing injected with a steady stream of energy, in the area along the OBOR strategic background, service outsourcing contracts in our province, turnover, contracts can be expanded. Scope of business covers the technical contract, software development, data processing and so on each domain, contains all parts of the service outsourcing industry chain, compared with other provinces, basically formed covering the ITO and BPO go hand in hand, to two or morethings KPO service outsourcing pattern.Look from international clients national regional sources, covering southeast Asia, Africa, America, Japan and other OBOR countries and regions, from the current situation of our province cities to undertake service outsourcing, by contractor are mainly concentrated in Hefei, Wuhu, Maanshan. Hefei as only a service outsourcing demonstration city in Anhui province, at also OBOR node city, in Anhui province to undertake all the development of OBOR offshore service outsourcing status is always in the first place.

\section{Empirical analysis of Offshore service outsourcing competitiveness of OBOR in Anhui province}

GEM model is a commonly used model of competitiveness evaluation.Reference Lu Chang-kou(2013) "to" loosen the GEM after correction model, the four factors on the unbundling to eight free factors.as the government, facilities, technology, human resources, market openness, industrial concentration, cost, demand and so on. Based on the literature retrieval, reading the previous research results and actual needs, 16 indexes were selected to make the eight factors quantifiable to make it comparable, Using SPSS20 to perform KMO test and test factor analysis is feasible,Take one authentication method will remove the collinearity severe variable, with the help of principal component analysis (pca), the maximum variance method to extract the common factor for simplifies the original variables and carries on the classification, named common factor according to the original variable the practical significance, then concluded the male factor expression, Finally, the model setting equation is obtained, further to get the ranking of service outsourcing competitiveness in the overlapping market of OB OR node and service outsourcing demonstration area and the development status of service outsourcing in Anhui province. 


\subsection{Data sources.}

Each city statistical yearbook and bulletin, 2016, from city to city technology bureau, business bureau, China service outsourcing network, cities service outsourcing network, cities service outsourcing association official website, etc.

\subsection{The selection of indicators.}

According to the GEM correction model, the eight elements index, finally chose 16 specific indicators to measure the eight elements of concrete as shown in table 1 , the X1 elements belong to the government, X2, X3, X4 belong to facilities; X5 and X6 represent technical elements; X7, X8, X9 represent human resource; X10 is the market factor. X11 and X12 represent industrial agglomeration elements. X13 and X14 represent cost, X15 and X16 are the requirement elements.

Table 1.evaluation index of OBOR service outsourcing competitiveness

\begin{tabular}{|c|c|c|c|}
\hline $\begin{array}{l}\mathrm{X} 1 \quad \text { Outsourcing } \\
\text { letter (note) }\end{array}$ & $\begin{array}{l}\text { X5 Number of } \\
\text { patent } \\
\text { applications }\end{array}$ & $\begin{array}{l}\text { X9 Number of college } \\
\text { students }\end{array}$ & $\begin{array}{lll}\text { X13 } & \text { Spending on } \\
\text { science } & & \end{array}$ \\
\hline $\begin{array}{l}\text { X2 Internet } \\
\text { access users }\end{array}$ & $\begin{array}{l}\begin{array}{l}\text { X6 The number } \\
\text { of } \\
\text { authorized }\end{array} \\
\text { patents }\end{array}$ & $\begin{array}{l}\text { X10 The actual } \\
\text { utilization of foreign } \\
\text { capital amount }\end{array}$ & X14 \\
\hline $\begin{array}{lr}\text { X3 The whole } \\
\text { society } \\
\text { consumption }\end{array}$ & $\begin{array}{ll}\text { X7 Number } & \text { of } \\
\text { employees } & \text { of } \\
\text { service } & \\
\text { outsourcing } & \end{array}$ & $\begin{array}{l}\text { X11 } \\
\text { Serviceoutsourcing } \\
\text { enterprise number }\end{array}$ & $\begin{array}{l}\text { X15 The amount } \\
\text { ofOffshore } \\
\text { serviceoutsourcing } \\
\text { execution }\end{array}$ \\
\hline $\begin{array}{l}\mathrm{X} 4 \text { Number of } \\
\text { mobile phone users } \\
\text { at the end of the } \\
\text { year }\end{array}$ & $\begin{array}{l}\text { X8 The number of } \\
\text { colleges and } \\
\text { universities }\end{array}$ & $\begin{array}{l}\text { X12 output of the } \\
\text { tertiary industry } \\
\text { accounts for \% of } \\
\text { GDP }\end{array}$ & $\begin{array}{l}\text { X16Gross } \\
\text { product }\end{array}$ \\
\hline
\end{tabular}

\subsection{The empirical analysis}

\subsubsection{Data inspection}

Data processing. According to the results of the SPSS20.0 operation because of KMO and bartlett measure value is empty, that show serious multicollinearity between the selected index, so the selection index for screening, after model modified, seven variable indicators left, $\mathrm{X} 1, \mathrm{X} 2, \mathrm{X} 7$, $\mathrm{X} 9, \mathrm{X} 10, \mathrm{X} 13, \mathrm{X} 15$. According to the correlation matrix table, most of the correlation coefficients are above 0.3 , which indicates that the overall factor analysis is suitable for the next test.

Table 2.correlation matrix

\begin{tabular}{r|r|r|r|r|r|r|r}
\hline & $\times 1$ & $\times 2$ & $\times 7$ & $\times 9$ & $\times 10$ & $\times 13$ & $\times 15$ \\
\hline$\times 1$ & 1.000 & .362 & -.007 & .833 & .579 & .808 & .554 \\
$\times 2$ & .362 & 1.000 & .450 & .534 & .921 & .004 & .891 \\
$\times 7$ & -.007 & .450 & 1.000 & -.005 & .441 & .266 & .265 \\
$\times 9$ & .833 & .534 & -.005 & 1.000 & .767 & .527 & .741 \\
$\times 10$ & .579 & .921 & .441 & .767 & 1.000 & .272 & .893 \\
$\times 13$ & .808 & -.004 & .266 & .527 & .272 & 1.000 & .146 \\
$\times 15$ & .554 & .891 & .265 & .741 & .893 & .46 & 1.000 \\
\hline
\end{tabular}

KMO and Bartlett's test. It can verify whether the data is suitable for further analysis of the factors, the results as shown in table 3 , KMO value is $0.503>0.5$, says can be used for the analysis of the factors, Bartlett's test of Sig. A value of $0.000<0.01$, explain data from normal distribution, the overall at the same time, Bartlett's test value of 49.498, the degrees of freedom for the 21st, reach the significance level, suitable for further analysis. 
Table 3.KMO and Bartlett tests

\begin{tabular}{|lr|c|}
\hline \multicolumn{2}{|l|}{ Take the Kaiser-meyer-olkin metric of sufficient } & .503 \\
sampling & & 49.498 \\
Bartlett & Sphericity $\quad$ testThe approximate & 21 \\
chi-square & & .000 \\
& df & \\
& sig. & \\
\hline
\end{tabular}

\subsubsection{Factor analysis}

Extraction factor.Because the variance of each indicator is 1, if the corresponding eigenvalue of the extracted common factor is less than 1, it is explained that this common factor cannot be explained by the variance of the most basic eigenvalue. So the public factor eigenvalue of the final extraction should be greater than or equal to 1 , and the greater the contribution rate of variance is, the more original information that is covered by the variance. In general, the accumulation of variance of principal components to $85 \%$ can better reflect the original problem. So it is appropriate to select the common factor with more than 1 and the cumulative contribution rate of more than $85 \%$.According to table 5 , the eigenvalues of the first three variables are greater than 1 , and the cumulative contribution rate of variance is $96.517 \%$, which indicates that the three factors interpretation is extremely high. So these factors are selected to replace the original seven variables. Initial eigenvalue Extract squares and loads Rotate squares and loads Constituent total\% variance cumulative total \% variance cumulative total \% variance cumulative

Table 4. Total variance explained

\begin{tabular}{l|r|r|r|r|r|r|r|r|r}
\hline 1 & 4.148 & 59.255 & 59.255 & 4.148 & 59.255 & 59.255 & 3.302 & 47.174 & 47.174 \\
2 & 1.577 & 22.532 & 81.787 & 1.577 & 22.532 & 81.787 & 2.267 & 32.380 & 79.554 \\
3 & 1.031 & 14.730 & 96.517 & 1.031 & 14.730 & 96.517 & 1.187 & 16.962 & 96.517 \\
4 & .140 & 2.007 & 98.524 & & & & & & \\
5 & .090 & 1.283 & 99.807 & & & & & & \\
6 & .011 & .154 & 99.962 & & & & & & \\
7 & .003 & .038 & 100.000 & & & & & & \\
\hline
\end{tabular}

The factor setting.Uses F1, F2, F3 to represent the three common factors of extraction; Table 5 shows the load of the original seven variables on three common factors when the maximum variance method is rotated. The results show that the coefficient of the first factor in X2, X10 and $\mathrm{X} 15$ indicates that F1 mainly explains the three variables, and the second common factor mainly explains X1 and X13. The third factor explains X7; The three common factors are named F1technology brand, F2- policy and F3 -human resource, also "F"- Outsourcing competitiveness a respectively,ccording to the actual variables contained in each common factor.

The common factor expression. According to table 6, the factor score coefficient matrix can be obtained by the scoring formula of each common factor, where the positive number is higher than the mean value, and the negative number is below the mean value:

$\mathrm{F} 1=0.003 \mathrm{X} 1+0.340 \mathrm{X} 2-0.069 \mathrm{X} 7+0.170 \mathrm{X} 9+0.271 \mathrm{X} 10-0.254 \mathrm{X} 13+0.332 \mathrm{X} 15$

$\mathrm{F} 2=0.397 \mathrm{X} 1-0.188 \mathrm{X} 2+0.019 \times 7+0.211 \mathrm{X} 9-0.020 \mathrm{X} 10+0.546 \mathrm{X} 13-0.083 \mathrm{X} 15$

$\mathrm{F} 3=-0.143 \mathrm{X} 1+0.091 \mathrm{X} 2+0.845 \mathrm{X} 7-0.268 \times 9+0.084 \mathrm{X} 10+0.270 \mathrm{X} 13-0.101 \mathrm{X} 15$

\subsection{The empirical results}

In order to evaluate the competitiveness of Hefei and other OBOR node urban service outsourcing, the variance contribution rate of each common factor was selected as the coefficient, and the model of service outsourcing competitiveness was constructed. The expression was:

$\mathrm{F}=0.59255 \mathrm{~F} 1+0.22532 \mathrm{~F} 2+0.14730 \mathrm{~F} 3$ 
Table 5. competitiveness ranking of service outsourcing

\begin{tabular}{c|c|c|c|c|c|c|c|c}
\hline City & \multicolumn{2}{|c|}{$\mathrm{F}$} & \multicolumn{2}{c|}{$\mathrm{F} 1$} & \multicolumn{2}{c|}{$\mathrm{F} 2$} & \multicolumn{2}{c}{ F3 } \\
\hline \multirow{2}{*}{ Chongqing } & rank & score & rank & score & rank & score & rank & score \\
\cline { 2 - 10 } & 1 & 187.2 & 1 & 346.6 & 8 & -129 & 1 & 75.33 \\
\hline Chengdu & 2 & 131.7 & 2 & 239.3 & 7 & -78 & 2 & 51.99 \\
\hline Wuhan & 3 & 104.9 & 3 & 166.5 & 1 & 2.59 & 4 & 38.8 \\
\hline Xian & 4 & 79.44 & 4 & 135.2 & 4 & -17.89 & 6 & 22.47 \\
\hline Zhengzhou & 5 & 75.73 & 5 & 132.7 & 6 & -44.42 & 3 & 48.11 \\
\hline Changsha & 6 & 57.64 & 6 & 97.17 & 3 & -14.44 & 5 & 22.52 \\
\hline Hefei & 7 & 50.28 & 7 & 88.6 & 5 & -22.31 & 7 & 19.06 \\
\hline Nanchang & 8 & 39.58 & 8 & 65.7 & 2 & -2.89 & 8 & 8.85 \\
\hline
\end{tabular}

According to table 5 service outsourcing competitiveness rankings by SPSS20.0 factor analysis, it is obvious that hefei service outsourcing comprehensive competitiveness is relatively low, compared with other cities of OBOR node city, and is in seventh place. And it comprehensive competitiveness index is much lower than Chongqing, Chengdu, Wuhan, its value is only 1/2 of Wuhan, technical brand ability is located in the seventh, the power of policies in the middle, human resource factor is in a weak position, its competitiveness overall equal to Changsha.

\section{Countermeasures to broaden the implementation of OBORoffshore services outsourcing for} Anhui province

\subsection{To implement the three-tiered market development strategy and expand the international service outsourcing by government}

Take priority, encourage and pay attention to the three-level market strategy, and gradually promote the outsourcing cooperation between Anhui and countries along OBOR. One is priority; Those areas in which the development of international trade is in good shape, and the economic and trade cooperation, especially in service outsourcing with China is frequent and solid.We need to play the role of the government, accelerate the construction of FTA, and promote the inter-governmental outsourcing cooperation to creating a favorable investment environment for our service outsourcing docking OBOR. Second, the level of encouragement;countries that take an active part in OBOR construction and their environment of market also stable should be encouraged to implement the strategy of cultivation by strengthen propaganda, let other countries know our service outsourcing service standards and methods, in our province to speed up the cross-border cross-industry alliance cooperation in order to obtain new key position. Third, attention level. Regions that are not sufficiently clear about the strategic attitude of OBOR, such as Afghanistan and Lebanon, should adopt the trend of development. Relying on government assistance programs and trade cooperation platform to promote the communication and interaction between us, interaction mainly involved the specific content of the service outsourcing cooperation to dig deeper into the cooperation opportunity.

\subsection{To strengthen our outsourcing enterprise competitiveness by industrial group construction and overseas acquisition}

The government should spur outsourcing enterprises to allocate resources rationally and improve the efficiency of resource use. Guide outsourcing enterprises to build service outsourcing industry circle through innovation such as mergers, acquisitions and asset reorganizations. The service outsourcing industry circle each takes KPO, ITO, BPO as the core to form the characteristic industrial chain. Our enterprises engaged in offshore outsourcing should adopt cross-border m\&a strategy: the first choice is the merger of enterprises with close cooperation and closer cooperation with the provincial contracting enterprises; Secondly, acquisitions the businesses playing service project complementaryto our province; Thirdly, the enterprise along with many deficiencies in 
which has a great prospect or has a certain brand influence should be arranged to be acquired, In order to improve the brand ability of our outsourcing enterprises.

\subsection{The school, industry association and enterprise tripartite cooperation, use the inside and outside base to cultivate OBOR international service outsourcing specialized personnel}

It is under the leadership of the led industry association, school talent training base with outsourcing enterprise cooperation, provide internships, professional qualification authentication, outsourcing standard training, employment recommendation service for students, service outsourcing practitioners. The key institutions of our province should reach a cooperation agreement with local well-known enterprises and invite well-known local enterprises to join the design arrangement of relevant courses. Configure base mentors who focuses on the practice teaching for students, so enterprise mentors should be experts preferably from a local service outsourcing enterprises and have rich experience. Last The cultivation of talents in the base should refer to the requirements of international service outsourcing in ISCC as the standard specification.

\subsection{Giving full play to the role of the service outsourcing association.}

Service outsourcing association is one of the important channel to understand information related to the subject, and service outsourcing association in ours official website often face technical problems, such as network paralysis reflected the importance of the construction of the service outsourcing association needs to be improved, at the same time, outsourcing association website information update not in time, full of obsolete data, also did not play its proper role. It is urgent to strengthen the training of website technicians and give play to industry associations. The service outsourcing association can regularly publish the laws and regulations, industry information and the latest service outsourcing policies and development trends of OBOR on the official website. Settings section for outsourcing companies to collect the required documents and related data at the same time should also be actively involved in the strategy formulation process, and play role to docking policy for the government.

OBOR strategy provides the opportunity for Anhui leap-forward development, service outsourcing becomes popular in the world, when we understand the characteristics of the service outsourcing development in our country, and draw lessons from the development experience, In the context of building a new high ground for opening to the outside world,Anhui provincialstrategy to undertake OBOR offshore service outsourcing business give uspractical advice to develop international service outsourcing market, all the research is beneficial to the full extension of anhui service outsourcing industry.

\section{References}

[1] Grossman,Gene M,Elhanan.Outsourcing in a Global Economy[J].Review of Economic Studies,2004,5:37-46

[2] Bai Yunzhen. OBOR initiative and China's foreign aid transformation [J] world economy and politics, 2015 (11) : 53-71.

[3] Dai Jun. The current situation, problems and countermeasures of "One Belt And One Road" international service outsourcing in jiangsu under the new normal conditions [J]. External economy and trade 2017:3-4.

[4] Wang Yinglo. Introduction to service outsourcing [M]. xi 'an jiaotong university, 2010:33-33. 